\title{
Piptadenia gonoacantha-based natural dermocosmetic: a clinical trial
}

\section{Luciano Côrtes Paiva'(1), Karen Vieira da Silva'(i), Gabriel Feu Guarçoni de Almeida'(i), Eliana Amaro de Carvalho Caldeira"I(D), Carlos Eduardo Soares Gazzinelli Cruz ${ }^{\circledR}$, Patrícia de Oliveira Salgado'(1), Marilane de Oliveira Fani Amaro' ${ }^{10}$, Camilo Amaro de Carvalho' ${ }^{(1)}$}

\author{
I Universidade Federal de Viçosa, Viçosa, MG, Brasil \\ " Universidade Federal de Juiz de Fora, Juiz de Fora, MG, Brasil
}

\begin{abstract}
The use of phytotherapy expands the possibility of therapeutic resources for the population, often offering reduced costs when compared to the pharmaceutical industry. In this perspective, the JACBIO ${ }^{\circ}$ dermocosmetic ointment revealed, in non-clinical trials, its antibacterial and healing potential, with a great stimulating effect in increasing the production of images. This work aimed to carry out the clinical phase study on dermal toxicity, in serious humans, by applying $J A C B I O{ }^{\circledR}$, based on extracts from the leaves of Piptadenia gonoacantha (Pau Jacaré). The phase I randomized clinical trial was carried out with 28 clinically healthy patients at a public university in Minas Gerais, with no period from August to December 2018. The toxicological trial was developed with the intervention group that received a $J A C B I O \circledR$ dermatological ointment and the Placebo group. From the experimental protocol, participants were followed for four weeks. An analysis between the ointment and placebo groups, without reference to anticholinergic and cardiovascular events, showed no statistically significant difference. Likewise, there was no difference in laboratory results performed before and after treatment, both for the placebo group and for the intervention group. A low toxicity of the product indicates that this adjustment is safe and serves as a basis for phase II clinical trials in patients with lesions.
\end{abstract}

Keywords: Phytotherapy; Health; Pharmaceutical preparations; Clinical trial 


\section{INTRODUCTION}

The knowledge and use of plants in health care of the human being date from the emergence of mankind, when they were employed as teas, dressings and syrup, as therapeutic resources to recover and maintain the health (MACHADO et al. 2017). Among the applications, we can cite the treatment of wounds with poultices and other pharmaceutical forms. Souza and Rodrigues (2016) emphasize that the vegetable-origin inputs propitiated products for healing wounds, either with the traditional mode or by using the species as a source of active principle.

In Brazil, there is a great diversity of plants, but, its use as a therapeutic resource requires ethno-botanical and pharmacological knowledge to better understand the therapeutic and toxic properties of products of plant metabolism (MACHADO et al. 2017; MINISTÉRIO DA SAÚDE, 2016).

The literature data show that at least $25 \%$ of all modern drugs are derived directly or indirectly from medicinal plants, mainly through the application of technologies to traditional knowledge (MINISTÉRIO DA SAÚDE, 2016). The World Health Organization (WHO) (2011) emphasizes the importance of considering and valuing the medicinal plants in pharmaceutical assistance, mainly in relation to primary health care in developing countries.

The Ministry of Health (BR), through national and international policies, has encouraged the traditional medicine and complementary and alternative medicine (TM/CAM), and their products, especially the use of phytotherapy and medicinal plants in Primary Care. The aim of the MH is to expand the supply and access of the population to safe herbal products and their rational use, contributing to a more economical practice, aiming at a better attention to the health of the population. In this context, the National Policy on Complementary and Integrative Therapies form the Unified Health System (UHS), approved in 2006, corroborates the WHO's recommendations and proposes the deployment and appropriateness of actions and services, which include the use of phytotherapy and medicinal plants in the UHS (MINISTÉRIO DA SAÚDE, 2016). 
New studies have been developed in order to discover new therapies based on plants with medicinal properties to treat and heal injuries with satisfactory effect (SOUZA; RODRIGUES, 2016; RAMALHO et al. 2018), in addition to other clinical indications. Marigold (Calendula officinalis), Barbatimão (Stryphnodendron adstringens), Babosa (Aloe vera) and Diesel Tree (Copaiferalangs dorffi) stand out as cicatrizing and with tissue re-epithelialization properties for dermatological diseases, demonstrating a significant improvement in the evolution of the lesions (RAMALHO et al. 2018).

A systematic review study presented medicinal plants with antibacterial potential that act on Staphylococcus aureus, namely: Garlic (Allium sativum), Carqueja (Baccharis Trimera), Beggar-ticks (Bidens pilosa), Wild Marigold (Tagetes minuta), Chamomile (Matricaria chamomilla), Fennel (Foeniculum vulgare), Eucalyptus (Eucalyptus globulus), Brazilian Cherry (Eugenia uniflora), Mint (Mentha piperita), Ginger (Zingiber officinalle) (MARMITT et al. 2015).

Similarly, the extracts from leaves of Piptadenia gonoacantha (Pau Jacaré), the target of this study, have antimicrobial action, indicating a large application in purulent lesions (FRANCO, 2018). In addition, the extracts have anti-inflammatory, nociceptive (CARVALHO et al. 2011) and cicatrizing (RIBEIRO, 2018) activities, as well as lack of toxicity (FAUSTINO et al. 2017) proven through pre-clinical tests in animal models with mice and rats, all featuring great results.

The positive results in the pre-clinical phase indicate that the formulation is likely to be used in humans for dermatological infections. In the clinical phase, tests performed on humans, the trials aim to evaluate the efficacy and safety of products intended to the medical area. In this sense, the completion of phase I clinical trial is an important step to be followed, to further develop the phase II in order to attest the efficacy of pharmaceutical products. Although pre-clinical studies have pointed out that the extracts from leaves of Piptadenia gonoacantha (Pau Jacaré) are atoxic and have biological activity, the recommendation is to develop the clinical phase I first, because each phase has peculiarities that need to be met in order to obtain reliable scientific evidence (TENÓRIO et al. 2017). 
The proper treatment of the lesions is essential for the rapid recovery of the patient, which requires accurate scientific knowledge about the healing process and the inputs available in the market capable of accelerating it. From this perspective, it is possible to reduce the costs related to prolonged hospitalization for acute and chronic wounds and to provide the reintegration of the individual in society.

In the Brazilian market, several pharmaceutical products with differentiated prices are available. The choice of the type of treatment and dressing should respect and consider the status of the wound and operational technical and economic factors (SOUZAS, 2005; COSTA et al. 2015).

Considering the epidemiology of wounds, whether acute or chronic, and the expenses encumbered to the health system, this study proposes the investigation of the toxicity of a new formulation that can replace imports of products and inputs, adding density of knowledge to a national product. Thus, it is possible to increase the country's competitiveness in the global scenario, with the goal of expanding the possibilities of low-cost therapeutic resources to the UHS or the local market, for the treatment of cutaneous inflammatory and infectious processes.

The objective of this study was to carry out a study of clinical phase I concerning the dermal toxicity in healthy human beings, of the JACBIO® ointment based on extracts from leaves of Piptadenia gonoacantha (Pau Jacaré).

\section{MATERIAL AND METHOD}

A randomized phase I, parallel-controlled clinical trial, of the double-blind masking type and with stratified randomization technique was developed. It is important to highlight that researches conducted with this design are considered the gold standard in the production of clinical evidence (OSORIO-DE-CASTRO et al. 2012).

The present study was conducted in a federal higher education institution with graduate students from two courses in the health area, being randomly chosen. The sample size was defined according to the guidelines described by 
Osorio-de-Castro and colleagues (2012) and the Brazilian Society of Professionals in Clinical Research (2019), who argue from 20 to 100 healthy people for studies of clinical phase I.

The inclusion criteria were healthy individuals, male and female, aged from 18 to 35 years. The positive response to any one of the following criteria was considered as an exclusion criterion: change in laboratory tests requested by researchers associated with clinical signs and symptoms, pregnancy, regular use of drugs for chronic diseases, hypersensitivity to the components of the formulation studied or history of serious adverse reactions in any period of the study, smokers, consumers of alcoholic beverages, in general ( $80 \mathrm{ml}$ of alcohol/day), and those who had any comorbidity.

The participants could be withdrawn from the study in case they had adverse effects to the product under investigation; by unavailability or intolerance to the procedures adopted; or the desire not to continue in the study, as well as any condition that prevented them from continuing according to the researcher's judgment.

For access to the participants, the researchers publicized the research in the classroom in a university in Minas Gerais, inviting them to be volunteers. Initially, 37 people were willing, signing the Informed Consent Form. All of the volunteers were submitted to peripheral blood puncture, to assess the health condition, respecting the 12-hour fasting. The samples obtained were submitted to the following laboratory tests: complete blood count, blood glucose, serum creatinine, urea, aspartate aminotransferase (AST) and alanine aminotransferase (ALT), alkaline phosphatase and total cholesterol. For women, there was also the request of serum $\beta$-HCG (beta Human Chorionic Gonadotropin). The collection of peripheral blood was performed at the Laboratory of Clinical Analysis of the institution, by the professionals from the service itself. After evaluation of laboratory and physical tests by a medical professional, 28 individuals were considered clinically healthy. 
The phase I clinical toxicological trial was developed in the period from August to December 2018, in which the intervention group received the dermatological ointment called "Produtos Dermocosméticos JACBIO ${ }^{\circledR "}$.

The production of the $\mathrm{JACBIO}^{\circledR}$ ointment formulation used aerial parts of Piptadenia gonoacantha, collected in 2018, in the municipality of Viçosa - MG, following the protocols described in the patent application n. BR 1020180007831 and $\mathrm{JACBIO}^{\circledR}$ products trademark (Figure 1) n. 914251996 (CARVALHO, 2018) requested from INPI.

Figure 1 - Digital image of the product trademark requested from INPI. Process:

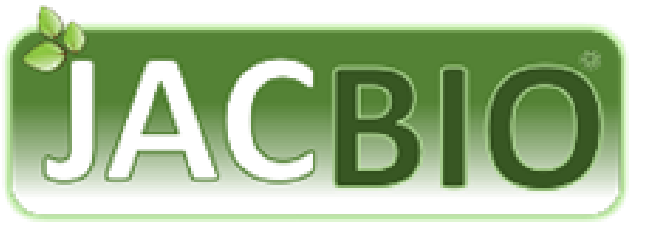

After selection, the participants received the $J A C B I O{ }^{\circledR}$ Dermocosmetic ointment $(n=14)$ or placebo $(n=14)$ for 28 consecutive days. They were randomly allocated in the groups, with this choice not suffering the direct interference of the researchers. For this reason, the double-blind masking type was applied, where neither the researchers who interacted directly with the volunteers, nor the participants themselves recognized to which group they belonged. Only two members of the research were aware of the treatments because knowing group to which one belongs induces both researchers and participants to overestimate or underestimate the effects of treatment (OSORIO-DE-CASTRO et al. 2012; HOCHMAN et al. 2005).

The two groups were treated daily, on the night shift, through dermal route, with healthy skin, in the forearm, right or left. In order to standardize the application of $\mathrm{JACBIO}^{\circledR}$ Dermocosmetic ointment sample, a mold produced with plastic material was developed, measuring $5 \times 5 \mathrm{~cm}$, with central opening of $2 \times 2$ 
$\mathrm{cm}$, with the ointment placed in the central area (Figure 2). The removal of the product occurred in the morning with soap and water. The participants themselves were responsible for the application, having been trained to use the mold and apply the formulation. They were advised to record any adverse reaction and communicate to members involved in the research.

Figure 2 - Representative scheme of the mold used to standardize the sample of the $J A C B I O^{\circledR}$ Dermocosmetic ointment applied to the forearm of the research volunteers

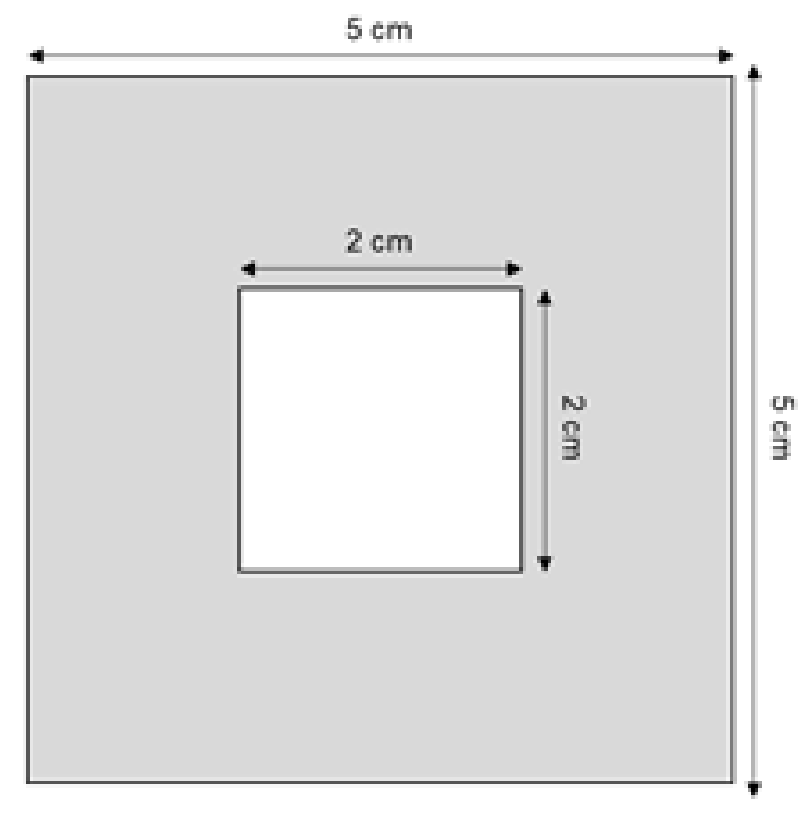

Weekly, the volunteers were evaluated by a physician, member of the research, for possible clinical changes from the experimental protocol. During the clinical evaluation, the research members answered a questionnaire that analyzed possible adverse reactions suggestive of the product toxicity. At the end of the research, laboratory tests were redone, in order to verify possible biochemical and/or hematological alterations relevant to the identification of possible toxicological effects.

The adverse events detected in the study period were recorded, regardless of whether or not related to the use of the product. The experimental protocol for 
investigation of possible adverse events was directed to the following clinical manifestations: anticholinergics, gastrointestinal, cardiovascular, neurological, psychiatric, and skin alterations. Any adverse event should be reported, as well as its day of the occurrence and if any medication was used in the period.

The database was composed of 28 individuals separated in $\mathrm{JACBIO}^{\circledR}$ Dermocosmetic ointment and placebo. They were analyzed regarding the occurrence of toxicities (hypersensitivity) and other variables related to the clinical condition, in addition to variables of characterization. In relation to toxicities, the individuals were observed over 28 days ( 4 weeks), and regarding the other variables related to clinical status, the individuals were evaluated from the results of two laboratory tests, before the research and after its conclusion.

In the descriptive analysis of the sample variables, the absolute and relative frequencies were used, and to compare the groups in relation to the variables of characterization, Chi-Square and Fisher's exact tests were used (AGRESTI, 2002).

For intragroup and intergroup analyses of the variables of interest, the GEE (Generalized Equations Estimating) method was used. This method is known as Marginal Models and can be considered an extension of Generalized Linear Models that directly incorporate the correlation between measurements of the same sample unit (MCCULLAGH; NELDER, 1989).

The intragroup analysis consists of comparing the times in each group, whereas the intergroup analysis consists of analyzing the homogeneity of the groups at each time. To check the influence of groups (ointment and placebo) on the toxicity over time, a Marginal Logistic Regression was adjusted (FITZMAURICE et al. 2011). Both analyses took into consideration the correlation between repeated measurements of the same individuals. The software used for the analyses was R (version 3.5.1).

The study followed the guidelines and regulatory standards for researches involving human beings, supporting the legislation contained in Resolution 466/2012. The Human Research Ethics Committee of the Federal University of 
Viçosa issued a favorable opinion, allowing the development of the study under opinion n. 2.587.961 (Table S1).

\section{RESULTS}

The descriptive analysis of the variables of interest was performed with data from the 28 study participants. For this purpose, the Chi-Square and Fisher's Exact Tests were, verifying an intragroup and intergroup homogeneity.

Of the participants, $57.1 \%(n=16)$ were female and $42.9 \%(n=12)$, male. In relation to body weight, $28.6 \%$ reported weight between 50 and $60 \mathrm{~kg}(\mathrm{n}=8), 35.7 \%$ $(n=10)$ between 61 and $70 \mathrm{~kg}, 14.3 \%(n=4)$ between 71 and $80 \mathrm{~kg}$ and $21.4 \%(n=6)$ mentioned above $80 \mathrm{~kg}$. Regarding stature, 92\% reported height greater than 1.60 meters. Concerning the comparison of groups between sexes, body weight and height ranges, there was no significant difference $(p>0.05)$. Table 1 shows the characteristics of participants included in the study.

Table 1 - Descriptive analysis of the characterization of participants of the $\mathrm{JACBIO}^{\circledR}$ Ointment or placebo group, 2019

\begin{tabular}{|c|c|c|c|c|c|c|c|c|}
\hline \multicolumn{2}{|c|}{ VariablesIGroups } & \multicolumn{2}{|c|}{ General } & \multicolumn{2}{|c|}{ Placebo } & \multicolumn{2}{|c|}{$\begin{array}{l}\text { JACBIO }^{\circledR} \\
\text { Ointment }\end{array}$} & p-value \\
\hline \multirow{2}{*}{ Sex } & Female & 16 & 57.1 & 8 & 50.0 & 8 & 50.0 & \multirow{2}{*}{$1.000^{1}$} \\
\hline & Male & 12 & 42.9 & 6 & 50.0 & 6 & 50.0 & \\
\hline \multirow{4}{*}{$\begin{array}{l}\text { Body weight } \\
\text { (kg) }\end{array}$} & $50-60$ & 8 & 28.6 & 4 & 50.0 & 4 & 50.0 & \multirow{4}{*}{$0.748^{2}$} \\
\hline & $61-70$ & 10 & 35.7 & 6 & 60.0 & 4 & 40.0 & \\
\hline & $71-80$ & 4 & 14.3 & 1 & 25.0 & 3 & 75.0 & \\
\hline & Over 80 & 6 & 21.4 & 3 & 50.0 & 3 & 50.0 & \\
\hline \multirow{2}{*}{ Stature (m) } & Below 1.60 & 2 & 7.1 & 1 & 50.0 & 1 & 50.0 & \multirow{2}{*}{$1.000^{2}$} \\
\hline & Over 1.60 & 26 & 92.9 & 13 & 50.0 & 13 & 50.0 & \\
\hline
\end{tabular}

Source: Research data. ${ }^{1}$ Chi-Square Test; Fisher's Exact Test ${ }^{2}$ 


\subsection{Description of adverse events}

The JACBIO ${ }^{\circledR}$ ointment (Figure 3) formulation was well tolerated by volunteers; however, some clinical manifestations were reported during the treatment period (Table 1S - Supplementary Material). For the Placebo group, there were 46 reports; in the $\mathrm{JACBIO}{ }^{\circledR}$ Dermocosmetic group, there were 23 reports.

Figure 3 - Representative scheme of the clinical trial

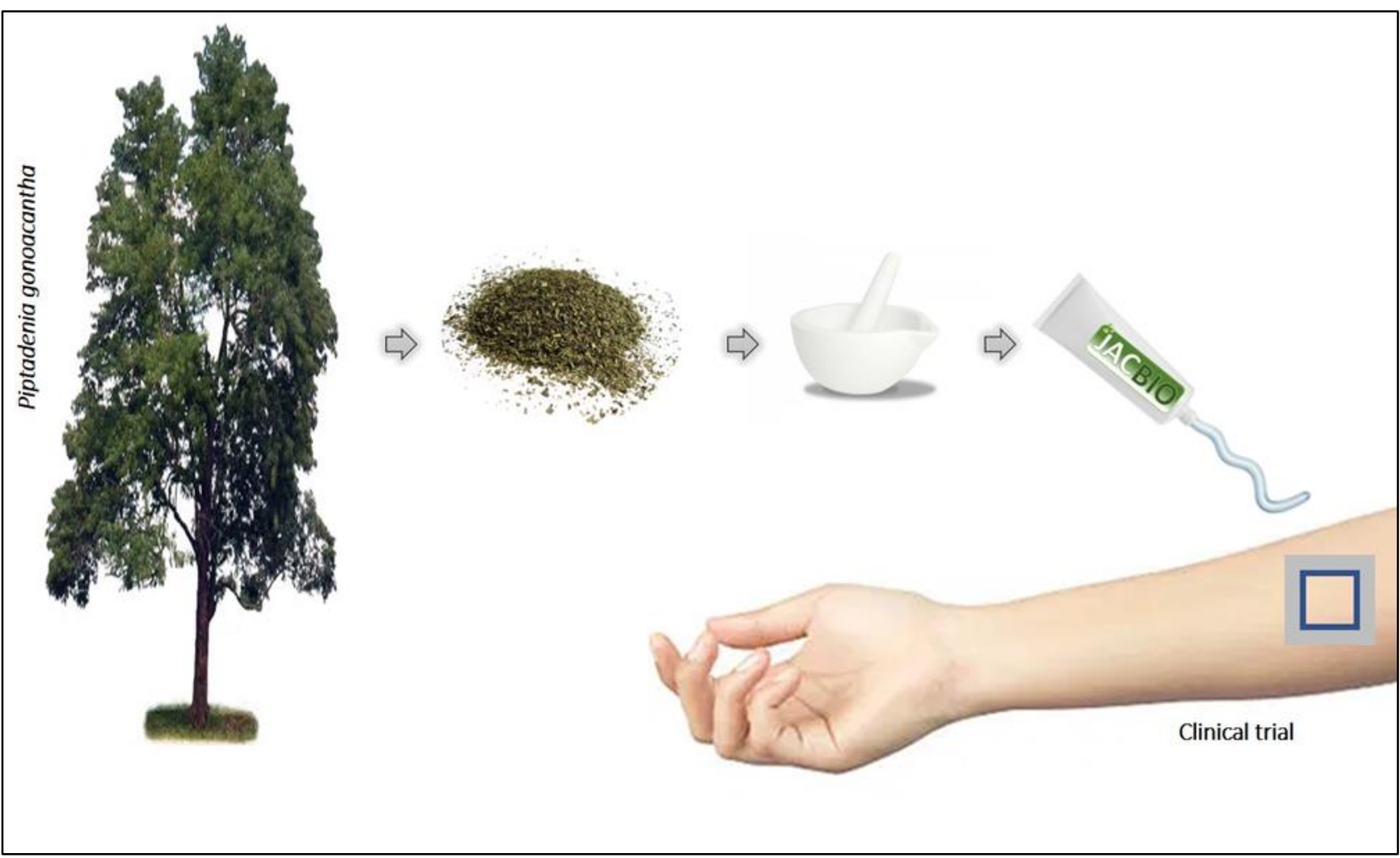

Episodes of headache were the most mentioned with 11 occurrences in four weeks. In second place, there were episodes of anxiety, reported by eight volunteers. Changes such as dry mouth, somnolence and insomnia were identified in five volunteers. Insomnia was described, in both groups, on the second and fourth week of treatment.

Symptoms of constipation and vomiting in the $\mathrm{JACBIO}^{\circledR}$ Dermocosmetic group and strange taste in the mouth in the Placebo group were described four 
volunteers each. The events of nasal dryness, intestinal cramps, agitation, dizziness and tingling obtained three reports each one.

The occurrence of lack of appetite was described once by the JACBIO ${ }^{\circledR}$ Dermocosmetic group and once by the Placebo group. The volunteers in the Placebo group reported only once the adverse events such as nausea, diarrhea and tachycardia, and hypotension and disorientation in the JACBIO ${ }^{\circledR}$ Dermocosmetic group. There was no change in the skin in the volunteers who participated in the study, in both groups.

Table 2 presents the analysis of the groups $\left(\mathrm{ACBIO}{ }^{\circledR}\right.$ ointment and placebo) predicting adverse events related to the anticholinergic, gastrointestinal, cardiovascular, neurological, psychiatric and skin symptoms, using the Marginal Logistic Regression (FITZMAURICE et al. 2011), considering a significance level of $10.0 \%$ ( $p$-value $<0.100)$.

The comparative analysis between the Placebo and JACBIO ${ }^{\circledR}$ Dermocosmetic groups showed statistically significant difference $(p=0.080)$ in relation to the neurological adverse events. The volunteers who used the ointment were 0.30 $[0.08,1.16]$ times less likely to develop some event when compared to volunteers who made use of placebo.

Equally, regarding psychiatric adverse events, there was a statistically significant difference $(p=0.073)$ between the Placebo and JACBIO ${ }^{\circledR}$ Dermocosmetic groups. The volunteers who used the ointment were $0.36[0.12,1.10]$ times less likely to present some psychiatric event when compared to those who used placebo.

Concerning gastrointestinal adverse events, there was a statistically significant difference $(p=0.097)$ between the Placebo and JACBIO ${ }^{\circledR}$ Dermocosmetic groups. The volunteers who used the ointment were $0.35[0.10,1.20]$ times less likely to present some gastrointestinal event when compared to those who used placebo. 
The comparative analysis between the ointment and placebo groups, in relation to anticholinergic and cardiovascular events, revealed that there is a statistically significant difference, with a p-value of 0.468 and 1.000 , respectively.

Table 2 - Comparative analysis between the $\mathrm{JACBIO}^{\circledR}$ ointment and Placebo groups during the four weeks of application of the product, predicting the adverse events related to the anticholinergic, gastrointestinal, cardiovascular, psychiatric, neurological and skin symptoms, 2019

\begin{tabular}{|c|c|c|c|c|}
\hline Source & Group & O.R. & C.I. - 95\% & p-value ${ }^{1}$ \\
\hline \multirow{2}{*}{ Anticholinergic } & Placebo & 1.00 & - & \multirow{2}{*}{0.468} \\
\hline & Ointment & 1.73 & {$[0.39 ; 7.62]$} & \\
\hline \multirow{2}{*}{ Gastrointestinal } & Placebo & 1.00 & - & \multirow{2}{*}{0.097} \\
\hline & Ointment & 0.35 & {$[0.10 ; 1.20]$} & \\
\hline \multirow{2}{*}{ Cardiovascular } & Placebo & 1.00 & - & \multirow{2}{*}{1.000} \\
\hline & Ointment & 1.00 & {$[0.06 ; 16.39]$} & \\
\hline \multirow{2}{*}{ Psychiatric } & Placebo & 1.00 & - & \multirow{2}{*}{0.073} \\
\hline & Ointment & 0.36 & {$[0.12 ; 1.10]$} & \\
\hline Neurological & Placebo & 1.00 & - & 0.080 \\
\hline
\end{tabular}

Source: Research data. O.R. - Odds Ratio; C.I. - 95\% = 95\% Confidence Interval

\subsection{Description of laboratory changes}

Hematological and biochemical tests were performed before (pre-treatment - L1) and after (post-treatment - L2) the application of formulations. Important parameters were analyzed, namely: count of erythrocytes, hemoglobin concentration, determination of the hematocrit, leukocyte total and differential count, platelet count, glucose, urea, creatinine, total cholesterol (TC), glutamic oxalacetic transaminase/aspartate aminotransferase (GOT/AST), glutamic pyruvic transaminase /alanine aminotransferase (GPT/ALT) and alkaline phosphatase (AF).

With respect to platelets, in the intragroup and intergroup analysis, there were no statistically significant differences between the Placebo and JACBIO ${ }^{\circledR}$ Dermocosmetic groups in any of the periods evaluated, L1 and L2. The same occurred for the count of erythrocytes, hemoglobin and hematocrit determination. 
The comparisons of total leukocytes, held between the Placebo and JACBIO ${ }^{\circledR}$ Dermocosmetic groups, demonstrated, through data, no significant difference in the laboratorial evaluation L1 $(p=0.006)$ and L2 $(p=0.001)$ as well as the quantity of leukocytes, with the highest variable mean observed in the group of individuals who used the ointment at the two times. In contrast, in the intragroup comparison, there were no statistically significant differences.

In the intergroup comparisons of the neutrophil parameter, there were statistically significant differences at the $L 1(p=0.028)$ and L2 $(p=0.002)$, with the highest variable mean observed in the group of volunteers who used the JACBIO ${ }^{\circledR}$ Dermocosmetic ointment at the two times. Nonetheless, when performed intragroup comparisons, there were no statistically significant differences.

In the intergroup analysis, the monocytes parameter, there were statistically significant differences between the groups in the laboratory $L 2(p=0.021)$, with the highest variable mean observed in the group of volunteers who used the JACBIO ${ }^{\circledR}$ Dermocosmetic ointment at the two times. In the intragroup comparison, there were no significant differences in none of the laboratories.

In the dosage of urea, intergroups, there were statistically significant differences in the L2 $(p=0.031)$, with the highest variable mean observed in the group of volunteers who used the $\mathrm{JACBIO}^{\circledR}$ Dermocosmetic ointment

Intra-groups, there was no significant difference in any variable between the two laboratories, for both the Placebo and the JACBIO ${ }^{\circledR}$ Dermocosmetic groups, given that none of the $p$ values was smaller than 0.050 .

The data described in Table 3 allow an intragroup and intergroup comparison, of Placebo and $\mathrm{JACBIO}^{\circledR}$ Dermocosmetic, with respect to the laboratory results at L1 and L2. 
Table 3 - Intragroup and intergroup comparison of the laboratory results before (L1) and after the treatment (L2) between the participants who used the $\mathrm{JACBIO}^{\circledR}$ Dermocosmetic ointment and Placebo, 2019

\begin{tabular}{|c|c|c|c|c|c|c|}
\hline \multirow{2}{*}{ Variables } & \multirow{2}{*}{ Laboratory } & \multicolumn{2}{|c|}{ Placebo } & \multicolumn{2}{|c|}{ Ointment } & \multirow{2}{*}{$\begin{array}{l}\text { Placebo x } \\
\text { Ointment }\end{array}$} \\
\hline & & Mean (S.D.) & p-value & Mean (S.D.) & p-value & \\
\hline \multirow{2}{*}{ Red cells } & L1 & $4.96(0.39)$ & \multirow{2}{*}{0.640} & $5.03(0.47)$ & \multirow{2}{*}{0.979} & 0.691 \\
\hline & $\mathrm{L} 2$ & $5.03(0.44)$ & & $5.03(0.41)$ & & 0.978 \\
\hline \multirow{2}{*}{$\mathrm{HB}$} & $\mathrm{L} 1$ & $14.09(0.94)$ & \multirow{2}{*}{0.563} & $13.99(1.58)$ & \multirow{2}{*}{0.842} & 0.844 \\
\hline & $\mathrm{L} 2$ & $14.31(1.21)$ & & $14.10(1.36)$ & & 0.648 \\
\hline \multirow{2}{*}{$\mathrm{HT}$} & L1 & $39.56(7.43)$ & \multirow{2}{*}{0.206} & $42.12(3.92)$ & \multirow{2}{*}{0.941} & 0.236 \\
\hline & $\mathrm{L} 2$ & $42.21(3.34)$ & & $42.02(3.53)$ & & 0.882 \\
\hline \multirow{2}{*}{ Leukocytes } & L1 & $\begin{array}{c}5217.62 \\
(1722.97) \\
\end{array}$ & \multirow{2}{*}{0.506} & $\begin{array}{c}7014.29 \\
(1860.46) \\
\end{array}$ & \multirow{2}{*}{0.372} & 0.006 \\
\hline & L2 & $\begin{array}{c}5585.71 \\
(1282.94) \\
\end{array}$ & & $\begin{array}{c}7628.57 \\
(1921.31) \\
\end{array}$ & & 0.001 \\
\hline \multirow[b]{2}{*}{ Eosinophils } & $\mathrm{L} 1$ & $127.14(102.37)$ & \multirow[b]{2}{*}{0.603} & 166.07 (91.69) & \multirow[b]{2}{*}{0.255} & 0.271 \\
\hline & L2 & 149.07 (127.98) & & $\begin{array}{c}212.07 \\
(127.47) \\
\end{array}$ & & 0.176 \\
\hline \multirow{2}{*}{ Neutrophils } & L1 & 3142.71 (778.58) & \multirow{2}{*}{0.638} & $\begin{array}{c}3980.14 \\
(1259.87) \\
\end{array}$ & \multirow{2}{*}{0.341} & 0.028 \\
\hline & $\mathrm{L} 2$ & $\begin{array}{c}2986.71 \\
(1024.45) \\
\end{array}$ & & $\begin{array}{c}4463.07 \\
(1515.48) \\
\end{array}$ & & 0.002 \\
\hline \multirow{2}{*}{ Lymphocytes } & L1 & $\begin{array}{c}3378.36 \\
(5124.97) \\
\end{array}$ & \multirow{2}{*}{0.306} & $\begin{array}{l}2375.57 \\
(519.06) \\
\end{array}$ & \multirow{2}{*}{0.995} & 0.450 \\
\hline & L2 & 2019.36 (531.39) & & $\begin{array}{l}2376.79 \\
(478.88) \\
\end{array}$ & & 0.052 \\
\hline \multirow[t]{2}{*}{ Monocytes } & L1 & $340.36(81.16)$ & \multirow[t]{2}{*}{0.615} & $\begin{array}{c}398.71 \\
(228.81) \\
\end{array}$ & \multirow[t]{2}{*}{0.412} & 0.351 \\
\hline & $\mathrm{L} 2$ & $359.79(126.23)$ & & $450.21(84.16)$ & & 0.021 \\
\hline Platelets & L1 & 221.64 (58.43) & 0.830 & $\begin{array}{c}253.93 \\
(114.32) \\
\end{array}$ & 0.848 & 0.329 \\
\hline & $\mathrm{L} 2$ & $217.14(56.36)$ & & $247.50(61.84)$ & & 0.159 \\
\hline Rlond alucoco & $\mathrm{L} 1$ & $81.07(4.57)$ & 0121 & $81.21(7.95)$ & 0112 & 0.952 \\
\hline Diudu giucuse & $\mathrm{L} 2$ & 84.71 (7.90) & $0.1<1$ & $85.64(7.35)$ & 0.112 & 0.738 \\
\hline Uron & $\mathrm{L} 1$ & $24.29(8.19)$ & 0817 & $25.93(7.95)$ & 0121 & 0.576 \\
\hline vied & $\mathrm{L} 2$ & $24.86(4.94)$ & 0.017 & 30.57 (9.02) & 0.134 & 0.031 \\
\hline Croptining & $\mathrm{L} 1$ & $7.79(25.68)$ & & $9.09(30.20)$ & & 0.898 \\
\hline creatinine & $\mathrm{L} 2$ & $0.94(0.15)$ & 0.301 & $1.03(0.13)$ & 0.300 & 0.092 \\
\hline TC & L1 & $163.00(40.78)$ & 0.689 & $184.29(28.83)$ & 0.619 & 0.098 \\
\hline & $\mathrm{L} 2$ & $156.71(45.42)$ & & $178.29(37.01)$ & & 0.153 \\
\hline GOT/AST & $\mathrm{L} 1$ & $23.36(5.03)$ & 0.502 & $22.64(6.37)$ & 0284 & 0.733 \\
\hline GUIIASI & $\mathrm{L} 2$ & $24.57(4.89)$ & 0.502 & $25.29(7.15)$ & 0.204 & 0.749 \\
\hline GPT/AIT & L1 & $22.07(7.28)$ & 0090 & $18.00(4.44)$ & 0918 & 0.064 \\
\hline GPI/ALI & $\mathrm{L} 2$ & $18.07(5.57)$ & 0.090 & $17.71(9.80)$ & 0.918 & 0.902 \\
\hline & $\mathrm{L} 1$ & $62.64(19.86)$ & & $68.07(21.57)$ & & 0.472 \\
\hline AP & $\mathrm{L} 2$ & $63.14(17.23)$ & 0.941 & $69.71(14.83)$ & $0.80 \%$ & 0.262 \\
\hline
\end{tabular}

Source: Research data. HT - Hematocrit; HB - Hemoglobin; TC - Total Cholesterol; GOT/AST - Glutamic Oxalacetic Transaminase/Aspartate Aminotransferase; GPT/ALT - Glutamic Pyruvic Transaminase/Alamine Aminitransferase; AP - Alkaline Phosphatase 


\section{DISCUSSION}

The use of phytotherapy expands the possibility of therapeutic resources to the population, many times offering with reduced costs when compared to the pharmaceutical industry. Gradually, this feature has been introduced in Brazil and has gained credibility in the market. Investment in researches in this area should be considered in order to seek new technologies, with a cost accessible to the population and greater effectiveness. In this perspective, the JACBIO ${ }^{\circledR}$ Dermocosmetic ointment has already revealed, in non-clinical trial, its antibacterial and healing potential, with great stimulating effect in increased production of collagen (FRANCO, 2018; RIBEIRO, 2018).

Medicinal plants can be used as healing, however, they need to be subjected to experimental studies for proof. Among the medicinal plants, there stand out those with direct effect on the healing of wounds or those with anti-inflammatory or antimicrobial potential. The use needs to be safe, requiring the investigation of various aspects from the chemical, pharmacological and toxicological point of view (PIRIZ et al. 2015).

The differential of the product evaluated in this study is its natural active principle, stimulating increased production of collagen and contributing to the formation of scars with thicker tissues. It is a product derived from a line of lowcost viable products and with great results in the pre-clinical phase, whose main active fluid extract comes from the leaves of Piptadenia gonoacantha (CARVALHO et al. 2011).

Piptadenia gonoacantha (Mart.) J. F. Macbr. (Fabaceae), popularly known as Pau Jacaré, is a fast growing tree. It has a wide geographic occurrence, being found in the states of Rio de Janeiro, Minas Gerais, São Paulo, Goiás and Mato Grosso do Sul through Santa Catarina, mainly in the rain forests of Atlantic hillside. It is an interesting species for use in reforestation to recover degraded areas. The fact that the active input is removed from nature, a large-sized tree, widely distributed in 
the Atlantic forest and with easy proliferation, reduces the cost of the final formulation (ALMEIDA; CORTINES, 2008).

A research demonstrated, through pre-clinical trials, a greater regression of the area of the wound in mice (Balb C) treated with $J A C B I O{ }^{\circledR}$ formulations, when compared to the group of animals treated with silver sulfadiazine, besides providing reduced inflammatory process, thus initiating the proliferative phase of healing (RIBEIRO, 2018).

Another study evaluated the antimicrobial activity of extracts and Piptadenia gonoacantha-based JACBIO® Dermocosmetic formulations, revealing inhibition halos related to Staphylococcus aureus and Staphylococcus epidermidis, in both the ointment as formulations in gel, cream, balm and liquid soap, and may assist in the process of colonized wound healing. An important characteristic of the ointment is its lipophilic nature, in such a way that, when providing an occlusion in the dermis, the hydration on site increases and the penetration of the drug is facilitated (FRANCO, 2018).

After the pre-clinical phase, in order to determine the degree of safety of substances in the test, there is need for studies that seek to evaluate the toxicity, which should be tested in healthy individuals who respond to the effects of the molecule (OLIVEIRA, 2006).

The clinical trials are developed in four stages, with first (phase I) applied in healthy human beings to evaluate the safety and tolerance, for example, to a certain drug/medication before its commercialization, as the results generated are positive, the study progresses to subsequent stages. The generation of new technologies contributes to the resolution of health problems and offers something fresh to the market. All clinical trials must follow regulations as defined by the Research Ethics National Council and Anvisa (TENÓRIO et al. 2017).

Considering that the first clinical phase to be developed is with healthy volunteers, this study evaluated the possible toxic nature of the $\mathrm{JACBIO}^{\circledR}$ Dermocosmetic ointment when administered in humans. The evaluation of this 
possible toxicity occurred through the completion of hematologic, hepatic, renal and metabolic laboratory parameters and the presence of adverse events.

Participants selected for the intervention and control groups were homogeneous concerning the characterization, eliminating a number of parameters that could cause differences in results.

Medicinal plants may trigger adverse reactions due to interactions with foods or other medications, by elements of its own composition, or even by the patient's individual characteristics such as age, sex, physiological conditions, among others (BALBINUS; DIAS, 2010).

Studies with phytotherapeutic plants corroborate this research in relation to adverse events, highlighting the reports of headache and lack of appetite (MOTTA; BIANCHI, 2005; PAULO et al. 2009). Other symptoms were described, but the number of volunteers affected in relation to the total number was small, in addition to being sporadic, thus demonstrating being reversible mild reactions. Surprisingly, the placebo group had more adverse reactions than the intervention group.

In the present study, individuals who used the $\mathrm{JACBIO}^{\circledR}$ Dermocosmetic ointment showed a decrease in the risk of developing neurological, psychiatric and gastrointestinal adverse events when compared to those who used placebo.

Lima (2013) shows that the main adverse reactions reported by users of medicinal plants are diarrhea, hepatotoxicity, gastrointestinal alterations, inhibition of platelet aggregation, visual difficulty and neuronal excitability, which goes against the reports obtained from the volunteers who used the $\mathrm{JACBIO}^{\circledR}$ Dermocosmetic ointment.

The laboratory analysis of the samples compared before and after the treatment showed no statistical significance that could reveal toxicity of JACBIO ${ }^{\circledR}$ Dermocosmetic ointment in various organs and systems evaluated. The variations of laboratory tests were within the normal range for each parameter, and showed no signs of toxicity. 
In the laboratory tests requested for volunteers, the blood cells count stands out as an important marker of toxicity, since the hematopoietic system is sensitive to toxic agents, such as substances with mutagenic or cytotoxic potential (LORENZI, 2006). The interpretation of the hematological parameters showed that there was no statistically significant change to blood cells, hemoglobin and platelet total count.

Considering that many substances are biotransformed in the liver, the liver function was evaluated from measurements of GOT/AST and GPT/ALT, in addition to alkaline phosphatase, which is found predominantly in the bile, is an important marker of liver function (LIMA et al. 2001). In this study, there were no altered values of these variables between the initial evaluation through laboratory tests and after completion of the treatment, revealing an absence of hepatotoxicity.

The parameters total leukocytes, neutrophils, monocytes and urea showed a significant difference between the placebo and JACBIO ${ }^{\circledR}$ Dermocosmetic group, but does not reveal a significant change in the laboratory before and after the treatment of volunteers who were exposed to the extract of the Piptadenia gonoacantha contained in the evaluated formulation.

The present formulation tested in clinical stage I shows to be safe, but does not guarantee the absence of adverse reactions, especially the symptoms of low incidence, which is only possible to check in a larger sample.

\section{CONCLUSION}

The data obtained in this phase I clinical study allow for concluding that the application of the Piptadenia gonoacantha ointment in healthy individuals was well tolerated, with no clinical, laboratory alterations, and no significant adverse reactions. The results suggest the low toxicity of the product and indicate that this phytotherapeutic formulation can be used by the population. The choice of the 
JACBIO ${ }^{\circledR}$ Dermocosmetic ointment reduces the risk of gastrointestinal, neurological and psychiatric adverse events when compared to the Placebo group.

The Toxicology study showed that the JACBIO ${ }^{\circ}$ Dermocosmetic is safe, which will serve as the basis for phase II clinical trials, necessary for confirmation of clinical efficacy in humans of the products, in patients with lesions.

\section{REFERENCES}

AGRESTI A. Categorical analysis. New York: John Wiley; 2002.

ALMEIDA FS, CORTINES E. Population structure and spatial distribution of Piptadenia gonoacantha (Mart.) J.F. Macbr. Revista Floresta e Ambiente. 2008 [cited 2020 feb 10];15(2):18-23. Available from: http://www.floram.org/article/588e221 ae710ab87018b465b.

BALBINO EE, DIAS MF. Pharmacovigilance: a step towards the rational use of herbs and herbal medicines. Rev. bras. farmacogn. [Internet]. 2010 [cited 2020 feb 10];20(6):992-1000. Available from: http://www.scielo.br/scielo.php?pid=S0102695X2010000600027\&script=sci_abstract\&tlng=pt.

CARVALHO CA, FERNANDES KM, MATTA SLP, SILVA MB, OLIVEIRA LL, FONSECA CC. Evaluation of antiulcerogenic activity of aqueous extract of brassicaoleracea var. capitata (cabbage) on wistar rat gastric ulceration. Arq. gastroenterol. [Internet]. 2011 [cited 2020 feb 10];48(4):27682. Available from: http://www.scielo.br/scielo.php?script=sci_arttext\&pid=S000428032011000400011.

Carvalho CA, inventor; Formulações Dermocosméticas e/ou Farmacêuticas à base de Piptadenia gonoachanta com atividade antimicrobiana e uso. BR patente 102018000783 1. 2018.

COSTA AM, MATOZINHOS ACS, TRIGUEIROS OS, CUNHA RCG, MOREIRA LR. Costs of treatment pressure ulcer sinlong-term careunitin an institution of Minas Gerais. Enferm. rev. [Internet]. 2015[cited 2020 feb 10];18(1):58-74. Available from: http://periodicos.pucminas.br/index.php/enfermagemrevista/article/view/9378.

FAUSTINO MF, NONATO IA, FAUSTO GC, PINTO R, VALENTE FL, CARVALHO LM et al. Anthelmintic potential and in vivo acute toxicity study of Piptadenia gonoachanta leaf aqueous extract. J App Pharm Sc [Internet]. 2017 [cited 2020 feb 10];7(10):111-17. Available from: https://www.ejmanager.com/mnstemps/19/19-1495236155.pdf?t=1560296387.

FERREIRA ET, SANTOS ES, MONTEIRO JS, GOMES MSM, MENEZES RAO, SOUZA MJC. The use of medicinal and phytotherapy plants: an integrational review on the nurses 'performance. Braz. 
J. Hea. Rev. [Internet]. 2019 [cited 2020 feb 10];2(3):1511-23. Available from: http://www.brjd.com.br/index.php/BJHR/article/view/1383.

FITZMAURICE GM, LAIRD NM, WARE JH. Applied Iongitudinal analysis. 2 nd ed. Hoboken: Wiley; 2011.

FRANCO AJ. JACBIO ${ }^{\circledR}$ : Formulações Dermocosméticas e/ou Farmacêuticas à base de Piptadenia gonoacantha com atividade antimicrobiana e uso [dissertation]. Viçosa: Departamento de Medicina e Enfermagem/UFV; 2018.

HOCHMAN B, NAHAS FX, FILHO RSO, FERREIRA LM. Research designs. Acta cir. bras. [Internet] 2005 [cited 2020 feb 10];20 Suppl 2:S1-9. Available from: http://www.scielo.br/scielo.php?script=sci_arttext\&pid=S0102-86502005000800002.

LIMA AO, SOARES JB, GRECO J. Métodos de Laboratório Aplicados à Clínica. 8 th ed. Rio de Janeiro: Guanabara Koogan; 2001.

LIMA LO. Pharmacovigilance in Brazil: Overview of notifications in the scope of phytotherapy [dissertation]. Curitiba: Master in Pharmaceutical Sciences/UFPR; 2013. 177 p.

LORENZI TF. Manual de hematologia: propedêutica e clínica. 4 th ed. Rio de Janeiro: Medsi; 2006.

MACHADO MAB, ALMEIDA SA, SOUSA SRM, WOLF E, ALMEIDA JA. Plantas medicinais, características e usos: um estudo no contexto da educação do campo. Facit Business and Technology Journal [Internet]. 2017 [cited 2020 feb 10];2(1):1-24. Available from: http://revistas.faculdadefacit.edu.br/index.php/JNT/article/view/179.

MARMITT DJ, REMPEL C, GOETTERT MI, SILVA AC. Plants with potential antibacterial of national list Medical plants of health system only interest: systematic Review. Rev. Saúde Públ. Santa Cat. [Internet]. 2015 [cited 2020 feb 10];8(2):135-52. Available from: http://revista.saude.sc.gov.br/index.php/inicio/article/view/322/307.

MCCULLAGH P, NELDER JA. Generalized Linear Models. 2 nd ed. London: Chapman and Hall/CRC; 1989.

MINISTÉRIO DA SAÚDE (BR), Secretaria de Ciência, Tecnologia e Insumos Estratégicos, Departamento de Assistência Farmacêutica e Insumos Estratégicos. Política e Programa Nacional de Plantas Medicinais e Fitoterápicos [Internet]. Brasília: Ministério da Saúde; 2016 [cited 2020 feb 10]. Available from: http://bvsms.saude.gov.br/bvs/publicacoes/politica_programa_nacional_plantas_medicinais_fi toterapicos.pdf.

MOTTA AA, BIANCHI PG. Adverse drugs reactions. Rev Med. [Internet] 2005 [cited 2020 feb 10];84:10-17. Available from: https://www.revistas.usp.br/revistadc/article/download/59236/62252. 
OLIVEIRA GG. Ensaios Clínicos: princípios e prática. Brasília: Anvisa; 2006.

OSORIO-DE-CASTRO CGS, ESHER A, CHAVES GC. Pesquisa clínica. In: Rego S, Palácios M. Comitês de Ética em Pesquisa: Teoria e Prática. Rio de Janeiro: Fio Cruz; 2012.

PAULO PTC, DINIZ MFFM, MEDEIROS IA, MORAIS LCSL, ANDRADE FB, SANTOS HB. Phase I clinical toxicological assays of a complex herbal medicine (Schinus terebinthifolius Raddi, Plectranthus amboinicus Lour and Eucaliptus globulus Labill. Rev. bras. Farmacogn. [Internet] 2009 [cited 2020 feb 10];19(1A):68-76. Available from: http://www.scielo.br/pdf/rbfar/v19n1a/15.pdf.

PIRIZ MA, ROESE A, LOPES CV, SILVA MM, HECK RM, BARBIERI RL. Traditional use of medicinal plants to heal wounds: implications for nursing. Rev enferm UERJ [nternet]. 2015 [cited 2020 feb 10];23(5):674-9. Available https://www.epublicacoes.uerj.br/index.php/enfermagemuerj/article/view/5624/0.

RAMALHO MP, SANTOS SLF, CASTRO NM, VASCONCELOS LMO, MORAIS ICO, PESSOA CV. Medicinal plants in the process of wound healing: literature review. Rev. Expr. Catól. Saúde [Internet]. 2018 [cited 2020 feb 10];3(2):64-70. Available from: https://www.researchgate.net/publication/329722838_.

RIBEIRO CGP. Validação de formulações JACBIO $^{\circledR}$ a base de extratos de Piptadenia gonoacantha (Pau Jacaré) com atividade cicatrizante [dissertation]. Viçosa: Departamento de Medicina e Enfermagem/UFV; 2018.

BRAZILIAN SOCIETY OF PROFESSIONALS IN CLINICAL RESEARCH. Phases of a clinical study [Internet]. São Paulo: Brazilian Society of Professionals in Clinical Research; [cited 2020 fev 20]. Available from: https://www.sbppc.org.br/pesquisa-clinica.

SOUZA DR, RODRIGUES ECAMS. Medicinal Plants: Traditional Healers' Indications For The Treatment Of Wounds. Rev. Bras. Promoç. Saúde [Internet]. 2016 [cited 2020 feb 10];29(2):197-203. Available from: https://periodicos.unifor.br/RBPS/article/view/4390.

SOUZAS R. The health of the black population: a question of rights and equity. Rev. Educ. Pop. [Internet]. 2005[cited 2020 feb 10];4:94-102. Available from: http://www.seer.ufu.br/index.php/reveducpop/article/view/19919/10641.

TENÓRIO M, MELLO GA, VIANA ALA. Policies for fostering health science, technology and innovation in Brazil and the role of clinical research. Ciênc. Saúde Colet. [Internet]. 2017 [cited 2020 feb 10];22(5):1441-54. Available from: http://www.scielo.br/pdf/csc/v22n5/1413-8123-csc22-05-1441.pdf.

WORLD HEALTH ORGANIZATION. The world medicines situation 2011. Traditional medicines: global situation, issues and challenges [Internet]. Geneva: World Health Organization; 2011 [cited 2020 feb 10]. Available from: http://digicollection.org/hss/en/m/abstract/Js18063en/. 


\section{Authorship contributions}

\section{1 - Luciano Côrtes Paiva}

Universidade Federal de Viçosa, Viçosa, MG, Brasil. Departamento de Medicina e Enfermagem. Mestre em Ciências da Saúde.

https://orcid.org/0000-0002-9318-6769 - cortes_luciano@hotmail.com

Contribuição: Project administration

\section{2 - Karen Vieira da Silva}

Universidade Federal de Viçosa, Viçosa, MG, Brasil. Departamento de Medicina e Enfermagem. Graduando em Medicina.

https://orcid.org/0000-0001-9488-1627 - karenvieiradasilva@hotmail.com

Contribuição: Data curation

\section{3 - Gabriel Feu Guarçoni de Almeida}

Universidade Federal de Viçosa, Viçosa, MG, Brasil. Departamento de Medicina e Enfermagem. Graduando em Medicina.

https://orcid.org/0000-0001-9387-3588-g.feu@hotmail.com

Contribuição: Data curation

\section{4 - Eliana Amaro de Carvalho Caldeira}

Universidade Federal de Juiz de Fora, Juiz de Fora, MG, Brasil. Núcleo de Acessoria e Treinamento e Estudos em Saúde. Doutoranda em Saúde.

https://orcid.org/0000-0003-2070-2854 - elianaamaro23@hotmail.com

Contribuição: Data curation

\section{5 - Carlos Eduardo Soares Gazzinelli Cruz}

Universidade Federal de Viçosa, Viçosa, MG, Brasil. Professor do Departamento de Medicina e Enfermagem. Mestre em Ciências da Saúde.

https://orcid.org/0000-0002-2652-9178 - cadusgc@yahoo.com.br

Contribuição: Supervision

\section{6 - Patrícia de Oliveira Salgado}

Universidade Federal de Viçosa, Viçosa, MG, Brasil. Professora do Departamento de Medicina e Enfermagem. Doutora em Enfermagem.

https://orcid.org/0000-0002-0743-0244 - patriciaoliveirasalgado@gmail.com

Contribuição: Conceptualization

\section{7 - Marilane de Oliveira Fani Amaro}

Universidade Federal de Viçosa, Viçosa, MG, Brasil. Professora e pesquisadora do Departamento de Medicina e Enfermagem. Doutora em Biologia Celular e Estrutural. https://orcid.org/0000-0002-9495-0861 - marilaneamaro@yahoo.com.br Contribuição: Writing - original draft 


\section{8 - Camilo Amaro de Carvalho}

Universidade Federal de Viçosa, Viçosa, MG, Brasil. Professor pesquisador, Doutor em Biologia Celular e Estrutural.

https://orcid.org/0000-0001-9539-8653 - camiloamaro@yahoo.com.br

Contribuição: Project administration 